\title{
A Panel Examination of IFRS Adoption and Financial Statement Quality: Evidence from Selected Firms in Ghana
}

\author{
Richard Fosu Amankwa \\ University of Professional Studies \\ Accra, P. O. Box LG I49, Legon - Accra, Ghana \\ E-mail: richard.fosu@upsamail.edu.gh \\ John Kweku Mensah Mawutor \\ University of Professional Studies \\ Accra, P. O. Box LG I49, Legon - Accra, Ghana \\ E-mail:kwaku2mensah@gmail.com \\ Eric Boachie Yiadom \\ University of Professional Studies \\ Accra, P. O. Box LG I49, Legon - Accra, Ghana \\ E-mail: boachie.eric@upsamail.edu.gh
}

Received: August 16, 2020

Accepted: August 30, 2020

Online Published: September 16, 2020

doi: $10.46281 /$ ijafr.v5i2.768

URL: https://doi.org/I0.4628I/ijafr.v5i2.768

\begin{abstract}
This study examined the effect of IFRS adoption on the quality of financial statements of selected firms on the Ghana Stock Exchange. The study used the extent of management practices as a metric for financial statement quality. The audited annual reports of the selected firms from the GSE were analyzed using a panel regression model over the period 2001 -2006 and 2007 20I4. The study finds the adoption of IFRS to be significantly and negatively affect earnings management practices and, thus, improves financial statement quality. On the extent of earnings management practices, the study finds a decrease in the postadoption era as opposed to the pre-adoption era, signifying an improvement in accounting quality. The panel regression results show that adopting IFRS significantly decreases the extent of earnings management.
\end{abstract}

Keywords: IFRS, Financial Statement Quality, Earnings Management, Discretionary Accruals, Pre-Adoption, Post-Adoption.

\section{Background of the Study}

There is a growing need for financial statement harmonization across the globe, and for that matter, the International Financial Reporting Standards (IFRSs) adoption has taken center stage in the debate. To ensure that financial statements are uniform, reliable, and comparable, there are some qualitative characteristics enshrined in the IFRS that the preparers of financial statements must comply with. Some studies have suggested that the implementation of IFRS could ensure accounting harmonization because the IFRS directly improves the quality of financial statements. Psaros and Trotman (2004) indicated that using a single accounting standard can facilitate the enhancement of the quality of the financial statement.

The African economy has, in recent years, been exposed to international influences due to globalization. The surge in the adoption of the IFRS across Africa is against the background that the adoption of IFRS could increase investors' confidence, especially international investors (Okpala, 20I2). Consequently, greater FDI can be attracted to the continent (Gordon, Loeb, \& Zhu, 2012).

To reap the IFRS dividends, Ghana in 2007 also departed from the old Ghana National Accounting Standards (GNAS) and embraced the IFRS at the recommendation of the World Bank. The GNAS was gleaned from various accounting standards, including the UK accounting standards, the pre-IFRS standards, among others. This brought several inconsistencies in the standards and made it difficult to settle ambiguity anytime there is a disagreement between two or more standards (Agyei- 
Mensah, 2013). A post-adoption study among Ghanaian listed firms revealed that the implementation of IFRS generally reinforce accounting disclosure and therefore improve the quality of financial statement (Agyei-Mensah, 2013).

However, other studies in different jurisdictions have reported a possible adverse effect in the adoption of IFRS (Ahmed, Neel, \& Wang, 2013; Barth, Landsman, Lang, \& Williams, 2006). Barth et al. (2006) report the likelihood that IFRS may allow managers to be manipulative since the preparers of financial statements can exercise their discretion some issues.

This disagreement in the literature still leaves room to interrogate if IFRS implementation truly improves the quality of financial reporting of firms. Prior studies have been conducted with regards to the adoption of IFRS and financial statement quality. Kang (2013) investigates the effect of IFRS adoption on the financial reporting quality among some European firms. He used the earnings management approach and compared the outcome of the earnings management in the pre-and post-IFRS adoption period. His findings support the assertion that IFRS adoption enhances post-IFRS earnings management, indicating the higher quality in financial management. A similar study that lends support to Kang (2013) includes Pena and Franco (2017), Musa and Muhammad Tanimu (2017), and Umoren and Enang (2015).

There are divided views as to claims that IFRS enhances the quality of financial statements. Besides this, there is scanty evidence that supports or disagrees with the IFRS dividends, especially in the Ghanaian case. This study aims at consolidating the various views to re-visit the literature on the exact nexus between IFRS adoption and the quality of financial statements among some selected firms in Ghana. We broaden the measures of financial statement quality and use earnings management to investigate the quality of financial information in the pre and post-adoption of IFRS in Ghana. Our specific objective is, therefore, to test the impact of IFRS adoption on the quality of financial statements in Ghana.

\section{Literature Review}

The study is grounded on four core theoretical foundation; thus, the agency cost concept, the liberal concept, positive accounting concept, and public interest theory. The moral hazard scourge between management and shareholders widens the information asymmetry; hence, a stricter measure needs to be implemented to reduce the extent to which shareholders are affected by wrong information. Fields, Lys, and Vincent (200I) and Lambert (200I) assert that the adoption of IFRS may have a mediating ability to reduce hidden actions of management and thereby lessening agency cost. However, if there is no regulatory authority to enforce the implementation and adherence to the tenants of IFRS, management would continue to use shareholders' investment for personal gains. Moreover, the liberal methods in accounting can influence the quality of financial information. For every firm, non-fluctuating yearly earnings form the basis of choosing accounting methods that promise to deliver consistently high-quality earnings. Revsine, Collins, Johnson, Mittelstaedt, and Soffer (1999) found out the liberal method gives managers the flexibility to adopt an accrual accounting approach that smoothens uneven cash flow. The liberality theory gives room for subjective judgment; it may impair the relevance and quality of financial information. Also, Watts and Zimmerman (1986) theory of positive accounting hypothesizes that self-seeking economic agents like managers would engage in activities to maximize their interests. The PAT asserts that due to the rationale theory of choice, managers would choose accounting methods and concepts that promote the kind of financial information they intend to put across. Consequently,the extent of information asymmetry depends on the 'lenses' of managers and the quality of financial information. In a jurisdiction where effective financial reporting is practised, information asymmetry is minimized, stakeholder's confidence in management is renewed and the value of the firm ultimately surges upwards. Also, the Public interest Theory emerges to respond to consumer exploitation from some market actors. The theory emphasizes that there should be a regulator to protect the interest of the public (Smyth \& Söderberg, 20I0). IFRS comes in handy to ensure that management does not take advantage of the 'absentee' owner. The IFRS is intended to ensure optimum disclosure of financial information, which is detrimental to users.

\section{I Measuring Financial Statement Quality}

The literature has established that the financial statement should possess some characteristics to meet a defined accounting quality. The literature is divided as to how financial statement quality should be measured. However, the three dominant quality metrics include credit relevance metrics, value relevance metrics, and earnings management metrics. Firstly, credit relevance metrics measure financial quality from the creditor's perspective. Thus, preference is given to providing information that is useful to the needs of creditors. Here the use of credit ratings is very important; therefore, attempts are made to investigate the impact of firms' credit ratings on profitability and other survival indicators (Kosi, 2010). Secondly, the value relevance metrics are biased towards financial quality factors that help in predicting the market value of firms (Vishnani \& Shah, 2008). This approach is grounded on the fact that investors are concerned about share prices and returns; hence, accounting information should provide information to improve investment decisions. The value relevance metrics heavily rely on information such as earning ratio, dividend cover, interest cover, cash flows, earnings yield, firm size, among others. Lastly, earnings management metrics could be pervasive in reporting financial information in the absence of IFRS controls. Barth et al. (2006) think that the existence of IFRS eliminates the arbitrary use of accounting standards to achieve desired outcomes of management. The growing popularity and clarity of IFRSare, reducing the extent to which management uses their discretions, and as a result, the negative effects of earnings management practices on financial statement quality are minimized. 
There are extant studies on financial statement quality and IFRS adoption in general. Many authors continue to come up with different findings and conclusions in this growing debate. However, the number of empirical studies on the measurement of accounting quality under IFRS adoption using the quality metrics are relatively small. This study attempts to review the works already undertaken briefly and the various methodologies employed. This gives the review of the selected studies as they have been undertaken.

Tendeloo and Vanstraelen (2005), in their study undertaken on German companies, report no significant differences in the earnings management behavior between companies that uses local accounting standards like the German GAAP and the other counterparts that adopt IFRS. Thus, firms that voluntarily adopted did not witness any major variations in the postadoption periods.

Christensen, Lee, Walker, and Zeng (2015) conducted a study on the determinants of accounting quality changes around IFRS, more specifically, whether incentives or the standards influenced accounting changes. Their study centered on both earnings management (income smoothing and managing towards small positive profits) and timely loss recognition metrics. The finding from the study advances a weak relationship between financial statement quality and forceful adoption of IFRS; however, they asserted that voluntary adoption of IFRS rather enhances the quality of financial statements by reducing earnings management and timely loss recognition. Paanamen and Lin (2009), in their study, focusing on the value relevance, earnings management, and timely loss recognition metrics, also found out that accounting quality improved after the voluntary adoption of IFRS. Srivastava, Sunder, and Tse (2015) suggest in their study on IFRS on earnings management in China that earnings management through accruals has decreased in China since 2007 under IFRS, implying that there are immediate benefits for regulators, filers, information consumers, the accounting profession and other stakeholders. Uyar (2013) conducted a study on the impact of switching standards on accounting quality in Turkey using the earnings management (discretionary accruals, income smoothing, and small positive earnings), timely loss recognition, and value relevance metrics and made findings indicating that the quality of accounting improved with the market becoming more active.

Umoren and Enang (2015), in their study conducted among listed banks in Nigeria, also made findings that suggest that post-IFRS earnings per share are high relative to a counter period because the adoption of IFRS significantly improves financial statement quality, which in turn affects performance. Building on the above literature, it is worth examining whether the IFRS adoption and the firm financial measures (control variables) influence earnings management practices (discretionary accruals) significantly. As discussed above, it is expected that the adoption of IFRS will reduce the extent of earnings management practices of manufacturing firms listed on the Ghana Stock Exchange and hence, improve upon the quality of financial statements and accounting quality.

\section{Empirical Strategy}

The study is quantitatively designed. Data on financial statement quality and IFRS adoption is collected over $200 \mathrm{I}-2006$ (preIFRS adoption) and 2007-20I4 (post-IFRS adoption) periods from the Ghana Stock Exchange (GSE). The sample size includes II selected firms from the GSE, and the sampling techniques are purely based on the data available within the given time frame. The time periods for the study was chosen strategically to be able to assess the impact of IFRS adoption on the quality of financial statement among the sample size. To answer the research question, the Ordinary Least Squares (OLS) regression approach is used in analyzing the empirical model below. Following the works of Barth et al. (2006), Tendeloo and Vanstraelen (2005), and Iatridis (2010), we specify the following model:

\section{$D A_{i t}=a_{0}+a_{1} F_{i t}+a_{2} O C F_{i t}+a_{3} S I Z E_{i t}+a_{4} P R O F_{i t}+a_{5} L E V_{i t}+a_{6} G R W T H_{i t}+a_{7} A S S T T U R N_{i t}+\varepsilon_{i t}$}

Table I explains the variables in the model.

Table I. Definition of Variables

\begin{tabular}{ll}
\hline Variable & Scale \\
\hline $\boldsymbol{D} \boldsymbol{A}_{\boldsymbol{i t}}$ represents $\quad$ Discretionary & This is measured using the Jones Model; \\
Accruals of the firm ' $i$ ' at a time ' $t$. & $\frac{N O A}{A T A}=a_{0}+a_{1}\left(\frac{1}{A T A}\right)+a_{2}\left(\Delta\right.$ Sales $\left.-\frac{\Delta R e c}{A T A}\right)+a_{3}\left(\frac{G P P E}{A T A}\right)+\varepsilon$ \\
this definition of ' $i$ ' and ' $t$ ' is the & Where NOA=net operating accruals \\
same throughout the study & ATA= average total accruals \\
& $\Delta$ Sales = Change in Sales \\
& $\Delta$ Rec $=$ Change in accounts receivable \\
& GPPE= Gross Property, Plant and Equipment \\
& $\varepsilon=$ discretionary accruals estimate. \\
\hline
\end{tabular}




\begin{tabular}{|c|c|}
\hline $\begin{array}{l}\boldsymbol{F R S}_{\boldsymbol{i t}} \text { represents the Financial } \\
\text { Reporting System }\end{array}$ & $\begin{array}{l}\text { a dummy variable where FRS i, } \mathrm{t}=\mathrm{I} \text { for the financial statements companies which } \\
\text { have adopted IFRS, and FRS i, } \mathrm{t}=0 \text { for the company's financial statements that have } \\
\text { not adopted IFRS }\end{array}$ \\
\hline $\begin{array}{l}\boldsymbol{O C} \boldsymbol{F}_{\boldsymbol{i t}} \text { represents Cash Flow from } \\
\text { Operating Activities }\end{array}$ & This is measured by the multiplication of FRS and operating cash flows \\
\hline $\begin{array}{l}\boldsymbol{P R O F}_{\text {it }} \text { represents } \\
\text { Profitability }\end{array}$ & $\begin{array}{l}\text { This is measured by the multiplication of FRS and the operating profit margin of the } \\
\text { firm }\end{array}$ \\
\hline $\begin{array}{l}\boldsymbol{L} \boldsymbol{E} \boldsymbol{V}_{\boldsymbol{i t}} \text { represents } \\
\text { Leverage }\end{array}$ & $\begin{array}{l}\text { This is measured by the multiplication of FRS and total liabilities to shareholders' } \\
\text { funds }\end{array}$ \\
\hline 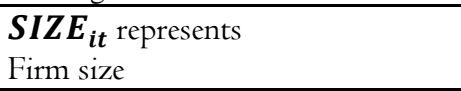 & This is measured by calculating the natural logarithm of the firm's total assets \\
\hline $\begin{array}{l}\text { GRWT H } \\
\text { Growth }\end{array}$ & This is measured by calculating the percentage in Revenue. \\
\hline $\begin{array}{l}\boldsymbol{A S S T T U R \boldsymbol { N } _ { i t }} \text { represents } \\
\text { Asset Turnover }\end{array}$ & This is measured by dividing the firm's revenue by its total assets \\
\hline $\begin{array}{l}\boldsymbol{\varepsilon}_{i t} \text { represents } \\
\text { error term }\end{array}$ & The error term \\
\hline
\end{tabular}

\section{I Justification of Variables}

The section below describes the type of data used in the empirical analysis and how discretionary accruals as the proxy for earnings management will be measured. Furthermore, the study includes certain control variables that are likely to influence the extent of earnings management practices (Kang, 2013).

Discretionary Accruals. Kang (2013) explains a discretionary accrual as a non-mandatory expense or asset that is recorded within the accounting system that has yet to be realized. An example is an anticipated bonus for management. The discretionary accruals are a better proxy for earnings management, which has the ability to capture the nature of financial statement quality (Kang, 2013).

Operating Cash Flows: A firm's cash flow operating cash flows helps in determining the extent of earnings management practices of the firm through its association with discretionary accruals. Keefe (2018) suggests the cash flow approach is better suited in describing accruals in all situations and almost impossible to get detailed information about accruals computation from the balance sheet. Iatridis (2010) found that a negative correlation between operating cash flows and discretionary accruals is indicative of earnings management in the organization.

Profitability. Profitability ratios are used to measure the company's ability to obtain profit during a specific period. Firm profitability is a key variable in relation to earnings management. Kargin (2013) give evidence to support the direct relationship between earnings management and profitability.

Firm size: Firm size is one value that can show the scale of how big a company is. The level of earnings management can be linked to the size of the firm as advanced by Kargin (2013). The bigger the firm, the higher the tendency to smoothen earnings and vice versa.

Leverage. Leverage is used to determine the amount needed to finance a company. Companies need to gain profit, and the higher the value of leverage held by the company, the higher the risk for investors who are trying to make their money back along with profit. According to Kang (20I3) and Tendeloo and Vanstraelen (2005), managers will likely undertake earnings management activities when the leverage ratio is high.

Growth: Growth is the value that shows how much the company has grown from the time it made it to the present point in time. With high growth, the manager will tend to lower its profits, which will then be allocated at a time the firm is experiencing a decrease in growth Kang (2013). The larger the company, the more money is needed for running the company, and this may lead to the manager engaging in management profit behaviors to attract investors or lenders (Tendeloo \& Vanstraelen, 2005)

Asset Turnover. Asset turnover is used as a measure of the efficiency of long-term capital investment, in which the ratio will reflect the level of sales generated in any investment that was imbedded in production capacity (Vishnani \& Shah, 2008). If the 
turnover is low, it indicates that the company was not able to capitalize on its assets as best as possible. So, companies with smaller ratios turn to massage the financial statement figures to make it appear as though the manager has performed well.

\section{Results and Discussion}

\section{I Descriptive Statistics}

The summary statistics are carried out in both pre-IFRS (Table 2) and post-IFRS (Table 3) adoption eras to give an in-depth understanding of the average indicators of the variables computed from the financial statements. On average, it is observed that under the pre-IFRS period, firms exhibit higher discretionary accruals (DA) than under post-IFRS adoption. It can also be observed that firms under pre-IFRS adoption generated more cash from operations than firms under post-IFRS adoption. Also, firms under post-IFRS adoption are more profitable than firms under pre-IFRS adoption. However, firms under post-IFRS adoption experienced a decline in leverage, growth, and asset turnover.

Finally, the average size of firms under post-IFRS size is 7.474 as compared to 6.969 in the pre-IFRS adoption, suggesting that the total assets of manufacturing firms listed on the Ghana Stock Exchange saw an upgrade after the adoption of IFRS.

Table 2. Descriptive Statistics (Pre-IFRS)

\begin{tabular}{lccccl}
\hline Variable & Mean & Std. Dev. & Min. & Max. & Obs. \\
\hline DA & 0.054 & 0.120 & -0.376 & 0.433 & $6 \mathrm{I}$ \\
\hline CFO & 0.119 & 0.275 & -0.746 & 1.360 & $6 \mathrm{I}$ \\
\hline SIZE & 6.969 & 0.680 & 5.595 & 8.080 & $6 \mathrm{I}$ \\
\hline PROF & 0.067 & 0.094 & -0.347 & 0.242 & $6 \mathrm{I}$ \\
\hline LEV & 1.240 & 1.012 & 0.079 & 6.258 & $6 \mathrm{I}$ \\
\hline GRWTH & 0.376 & 1.308 & -0.180 & 9.460 & $6 \mathrm{I}$ \\
\hline ASSTTURN & 1.270 & 0.604 & 0.366 & 3.248 & $6 \mathrm{I}$ \\
\hline
\end{tabular}

Table 3. Descriptive Statistics (Post-IFRS)

\begin{tabular}{llllll}
\hline Variable & Mean & Std. Dev. & Min. & Max. & Obs. \\
\hline DA & -0.019 & 1.648 & -0.345 & $0.79 \mathrm{I}$ & 87 \\
\hline CFO & $0.04 \mathrm{I}$ & 0.152 & $-0.5 \mathrm{I} 6$ & $0.60 \mathrm{I}$ & 87 \\
\hline SIZE & 7.474 & 0.737 & 5.952 & $8.74 \mathrm{I}$ & 87 \\
\hline PROF & 0.073 & 0.175 & -0.775 & $0.76 \mathrm{I}$ & 87 \\
\hline LEV & 1.203 & $1.22 \mathrm{I}$ & 0.052 & $7.5 \mathrm{II}$ & 87 \\
\hline GRWTH & 0.314 & 0.937 & -0.726 & 7.548 & 87 \\
\hline ASSTTURN & 1.018 & 0.472 & 0.228 & 2.998 & 87 \\
\hline
\end{tabular}

\subsection{Correlation Matrix}

From the correlation matrix, the firm financial measures, cash flows from operations, and profitability has negative and positive statistically significant relationships with discretionary accruals, respectively, whereas the other firm financial measures have no statistically significant relationships with discretionary accruals. Further, the financial reporting system in use has a positive statistically significant relationship with discretionary accruals as well as a negatively statistically significant relationship with cash flows from operations.

Profitability and asset turnover are positively statistically significant, with cash flows from operations, while the size and asset turnover are positively statistically significant and negatively statistically significant with the financial reporting system in use, respectively. Also, growth is positively and negatively statistically significant with leverage and size, respectively, while asset turnover is negatively and positively statistically significant with size and growth, respectively.

Table 4. Correlation matrix

\begin{tabular}{|c|c|c|c|c|c|c|c|c|}
\hline & $\mathrm{DA}$ & Cfo & FRS & Prof & Lev & Size & Grwth & Assettrn \\
\hline $\mathrm{DA}$ & 1.0000 & & & & & & & \\
\hline $\mathrm{CFO}$ & $-0.5966^{\text {tx }}$ & 1.0000 & & & & & & \\
\hline
\end{tabular}




\begin{tabular}{|c|c|c|c|c|c|c|c|c|}
\hline FRS & $0.2502^{\star *}$ & $-0.1797^{*}$ & 1.0000 & & & & & \\
\hline PROF & $0.264 \mathrm{I}^{*}$ & $0.2792^{\text {* }}$ & 0.0222 & 1.0000 & & & & \\
\hline LEV & 0.0255 & -0.1217 & -0.0158 & -0.1332 & 1.0000 & & & \\
\hline SIZE & 0.1498 & -0.1303 & $0.331 I^{*}$ & 0.1250 & -0.0544 & 1.0000 & & \\
\hline GRWTH & -0.0010 & 0.1127 & -0.0390 & 0.0494 & $0.2325^{* *}$ & -0.1719 * & 1.0000 & \\
\hline ASSETTRN & -0.1213 & $0.2179^{* *}$ & $-0.2298^{\text {xx }}$ & $0.2152^{* x}$ & -0.1129 & $-0.1645^{\text {荈 }}$ & $0.2447^{\text {* }}$ & 1.000 \\
\hline
\end{tabular}

*Significant at 5\%

\subsection{Correlation Matrix Showing the Relationship between discretionary accruals and operating cash flows in both pre- and post-IFRS adoption eras.}

The tables below show the correlation matrices for both pre-IFRS and post-IFRS adoption periods. The correlation matrices seek to achieve our first and second objectives, to determine the extent of earnings management practices before and after IFRS adoption, respectively. From the pre-IFRS correlation matrix, there is a negative relationship (-0.6574, significant at 0.000$)$ between Discretionary accruals and Cash flows from operations. This is an indication of earnings management practices within the industry, and about $65.74 \%$ of manufacturing firms within the pre-IFRS period practised income smoothing (earnings management). From the post-IFRS correlation matrix, there is also a negative relationship (-0.458I, significant at 0.000) between Discretionary accruals and cash flows from operations. This is also an indication of earnings management within the industry; however, only about $45.81 \%$ of manufacturing firms within the post-IFRS period practice income smoothing (earnings management), which is a decrease in comparison with the pre-IFRS period. The Pearson Correlation outcomes tend to be in line with results found in Barth et al. (2006) and demonstrates that under post-IFRS adoption, the relationship between discretionary accruals and cash flows from operations are closer to zero as compared to relationship results from the pre-IFRS period. This, in turn, suggests that IFRS adoption tends to reduce the extent of earnings management practices of manufacturing firms listed on the Ghana Stock Exchange.

Table 5. Pre-Analysis correlation matrix

\begin{tabular}{ccc}
\hline & $D A$ & $C F O$ \\
\hline DR & 1.0000 & \\
\hline CFO & $-0.6574^{* *}$ & 1.0000 \\
\hline${ }^{*}$ Significant at $5 \%$ &
\end{tabular}

Table 6. Post-Analysis correlation matrix

\begin{tabular}{lcl}
\hline & $D A$ & $C F O$ \\
\hline $\mathrm{DR}$ & 1.0000 & \\
\hline $\mathrm{CFO}$ & $-0.458 \mathrm{I}^{*}$ & 1.0000 \\
\hline
\end{tabular}

* Significant at $5 \%$

\subsection{Model Selection: Hausman Test}

The Hausman test, which is widely used in Panel data regression, is employed to test the appropriateness of the random effects model and fixed effects model. Hausman test examines the various estimation methods to determine the one which is consistent and efficient under the null and the alternative hypothesis. After running the test, the Hausman test suggested a fixed-effects model as the model that comes closest to the true data generating process and, therefore, more suitable for analysis.

Table 7. Hausman Test

\begin{tabular}{|c|c|c|c|c|}
\hline & \multicolumn{2}{|c|}{ Coefficients } & \multirow[b]{2}{*}{$(b-B)$} & \multirow[b]{2}{*}{$\operatorname{sqrt}\left(\operatorname{diag}\left(V_{-} b-V_{-} \_\right.\right.$B) $)$} \\
\hline & (b) & (B) & & \\
\hline Variable & $\mathrm{fe}$ & re & Difference & S.E. \\
\hline FRS & -.0760776 & .0248189 & -.1008964 & .0169169 \\
\hline SIZE & .165553 & -.0032782 & $.16883 \mathrm{I} 2$ & .0375569 \\
\hline PROF & .5017566 & .5000322 & .0017244 & .0096826 \\
\hline LEV & -.0239004 & -.0097559 & $-.014 \mathrm{I} 445$ & .0043152 \\
\hline
\end{tabular}




\begin{tabular}{ccccc}
\hline GRWTH & .0032659 & .0133037 & -.0100378 & - \\
\hline ASSTTURN & $-.012961 \mathrm{I}$ & -.0174369 & .0044758 & .0150554 \\
\hline CFO & -.6096977 & -.568857 & -.0408407 & - \\
\hline
\end{tabular}

$$
\begin{array}{r}
\operatorname{chi2}(7)=(\mathrm{b}-\mathrm{B})^{\wedge}\left[\left(\mathrm{V} \_\mathrm{b}-\mathrm{V} \_\mathrm{B}\right)^{\wedge}(-\mathrm{I})\right](\mathrm{b}-\mathrm{B})= \\
\text { Prob }>\text { chi } 2=0.0002 \\
0.0002
\end{array}
$$

\subsection{Regression Results}

Table 8. Ordinary Least Square Regression Results

\begin{tabular}{lcccc}
\hline Variable & Coef. & $\mathbf{P}>|\mathbf{t}|$ & $\mathbf{t}$ & Std. Error \\
\hline Constant & -1.088 & 0.000 & -3.82 & 0.285 \\
\hline CFO & -0.609 & 0.000 & -14.48 & 0.041 \\
\hline FRS & -0.076 & 0.003 & -3.09 & 0.024 \\
\hline PROF & 0.501 & 0.000 & 7.54 & 0.665 \\
\hline LEV & -0.024 & 0.008 & -2.71 & 0.088 \\
\hline SIZE & 0.165 & 0.003 & 4.21 & 0.039 \\
\hline GRWTH & 0.033 & 0.679 & 0.42 & 0.007 \\
\hline ASST_TURN & 0.038 & 0.571 & -0.57 & 0.022 \\
\hline R-squared & 0.3252 & & & \\
\hline Prob $>$ F & 0.0000 & & & \\
\hline
\end{tabular}

Table7 above presents results on the earnings management test that seeks to meet the second objective of this study; thus, determining the effect of IFRS adoption on earnings management practices (i.e., financial statement quality) along with other control variables. This is based on the OLS regression of discretionary accruals (a proxy for earnings management) on cash flows, profitability, leverage, size, growth, and asset turnover. From the regression analysis, FRS, which represents the Financial Reporting System in use, is significantly negative. This suggests that firms reporting under IFRS tend to exhibit lower accruals and thus are less likely to be prone to earnings management. In other words, IFRS reduces the earnings management practices of such firms. The contrary can be suggested about firms reporting under the pre-IFRS adoption era as they appear to exhibit higher accruals indicating their likelihood of proneness to earnings management. This is supported by the Public Interest Theory, which argues that the Regulatory agency, in this case, IFRS, is a "watchdog" that acts whenever the Public interest is about to be sacrificed. It can step in as a regulator to avoid a firm acting in a natural monopoly market prejudice consumers. These findings are consistent with the results perpetrated in the works of Iatridis (2010). In conclusion, this aids in achieving the final objective in determining the effect of IFRS on earnings management practices.

Also, the study results show that the effect of discretionary accruals on cash flows from operations (CFO) is negative at conventional levels. This implies that firms operating under IFRS adoption still engage in earnings management practices. Although a positively significant result was to be expected for the study, a negative one stills hold and is possible. This is backed by the Positive Accounting Theory that suggests that there is a positive outcome from the adoption of IFRS in reducing the extent of earnings management practices of firms. This result is also consistent with studies opined by Tendeloo and Vanstraelen (2005) and Iatridis (2010). For instance, Tendeloo and Vanstraelen (2005) advanced that an adverse correlation between accruals and operating cash flows indicates the likelihood that the accounting concept (accrual accounting) maybe use to ironout fluctuations in operating cash flows. They further stress that differences in the magnitude of the correlation could also indicate the extent to which accrual accounting is being used to smoothen operating cash flows.

Again, the results of the study also move on to show the effect of discretionary accruals and profitability (PROF) and provide a positively significant result. This implies that firms with low profitability after the adoption of IFRS would not tend to increase accruals and thus, reducing their scope of earnings management practices. On the other hand, a more profitable company is more likely to engage in earnings management as it makes the performance of the companies look better, which will result in managers getting a bigger bonus. That is to say, the higher the profitability ratio of the firm, the more the extent in earnings management practices. This result is consistent with studies conducted by (Governance, 2013; Nico \& Hengky, 2017).

Further, the study shows a positively significant result on the effect of discretionary accruals and firm size (SIZE). This connotes that larger firms under IFRS adoption display strong evidence of earnings management practices, and smaller firms display lower evidence of earnings management practices. This may be due to the argument that larger firms are exposed to 
greater public attention and could possibly have larger variations in earnings compared to smaller firms. Also, larger firms may face more pressure to manipulate earnings and have a stronger management power to make it easier in their earnings manipulation as compared to their smaller firm counterparts.

Finally, leverage (LEV) is reported to be negatively related to discretionary accruals. This implies that firms exhibiting high leverage would not be inclined to increase their accruals. This is because the increased debt of a firm might reduce the level of management's discretionary spending and, in turn, reduce earnings management. This result is consistent with studies conducted by (Zamri, Rahman, \& Isa, 2013), indicating that high leverage firms have lower levels of earnings management practices, which could, in turn, affect the quality of accounting earnings.

\section{Conclusion and Recommendations}

The study has investigated the extent to which earnings management practices among selected firms on the GSE. It has been evidenced that there is the existence of a statistically significant negative relationship between discretionary accruals (a proxy for earnings management) and cash flows from operations for both periods of financial systems in use. This indicates that firms reporting under pre-IFRS adoption are prone to earnings management as they exhibit higher accruals. However, in the postIFRS adoption era, although there is still a negatively significant relationship between discretionary accruals and cash flows from operations, there is a decline in the extent of earnings management practices. Also, the study revealed a negatively significant result between IFRS adoption and discretionary accruals, indicating that IFRS adoption improves upon accounting quality by reducing the income smoothing extent of firms. Hence, we conclude from the findings of the study that the adoption of IFRS is effective in improving the quality of financial statements.

The findings of the study go a long way to prove that IFRS adoption does indeed improve the quality of financial statements and accounting quality as a whole. Nevertheless, it is observed that this improvement is rather at a slower pace than expected. In that, even after IFRS adoption, there is still evidence of earnings management present in the industry. Strengthening the regulatory, supervisory framework that will, in turn, help investors make informed and unbiased decisions about their investments and the firm's future performance will aid in quickening the pace as well as providing positive results.

\section{References}

Agyei-Mensah, B. K. (2013). Adoption of international financial reporting standards (IFRS) in Ghana and the quality of financial statement disclosures. Macrothink Institute, International Journal of Accounting and Financial Reporting, ISSN, 2162-3082.

Ahmed, A. S., Neel, M., \& Wang, D. (2013). Does mandatory adoption of IFRS improve accounting quality? Preliminary evidence. Contemporary accounting research, 30(4), I344-I372.

Barth, M. E., Landsman, W., Lang, M., \& Williams, C. (2006). Accounting quality: International accounting standards and US GAAP. Manuscript, Stanford University, I-46.

Christensen, H. B., Lee, E., Walker, M., \& Zeng, C. (2015). Incentives or standards: What determines accounting quality changes around IFRS adoption?. European Accounting Review, 24(I), 3I-6I.

Fields, T. D., Lys, T. Z., \& Vincent, L. (200I). Empirical research on accounting choice. Journal of accounting and economics, 3I(I-3), 255-307.

Gordon, L. A., Loeb, M. P., \& Zhu, W. (2012). The impact of IFRS adoption on foreign direct investment. Journal of accounting and public policy, 3I(4), 374-398.

Governance, GC (2013). Amertha ISP, 2013, The Effect of Return On Asset on Earnings Management Practices with Moderated Corporate Governance, E-Journal of Accounting at Udayana University, 4(2), 373-387.

Iatridis, G. (2010). International Financial Reporting Standards and the quality of financial statement information. International review of financial analysis, I9(3), 193-204.

Kang, W. (2013). The impact of mandatory IFRS adoption on the earnings-returns relation. Applied Financial Economics, 23(I3), I I37-II43.

Kargin, S. (2013). The Impact of IFRS on the Value Relevance of Accounting Information: Evidence from Turkish Firms. International Journal of Economics and Finance, 5(4), 7I-80.

Kosi, U. (2010, May). Credit relevance of accounting information and mandatory IFRS adoption. In An Enterprise Odyssey. International Conference Proceedings (p. 662). University of Zagreb, Faculty of Economics and Business.

Lambert, R. A. (200I). Contracting theory and accounting. Journal of Accounting and Economics, 32(I-3), 3-87.

Musa, A., \& Muhammad Tanimu, I. (2017). International Financial Reporting Standards and Value Relevance of Financial Information: An Empirical Evaluation of Selected Nigerian Listed Companies. International Journal of Accounting \& Finance Review, I(I), I-II. https://doi.org/I0.4628I/ijafr.vIiI.I3

Nico, A., \& Hengky. (2017). Factors affecting earnings management in the Indonesian Stock Exchange. Journal of Finance and Banking Review, 2(2), 8-I4. 
Okpala, K. E. (20I2). Adoption of IFRS and Financial Statement Effects:The Perceived Implications on FDI and Nigeria Economy. Australian Journal of Business and Management Research.

Paanamen, M., \& Lin, H. (2009). The development of accounting quality of IAS and IFRS over time: the case of Germany. Journal of International Accounting Research, 8(I), 3I-35.

Peña, H. F. P., \& Franco, J. B. (2017). Impact of IFRS on the quality of financial information in the United Kingdom and France: Evidence from a new perspective. Intangible Capital, I3(4), 850-878.

Psaros, J. I. M., \& Trotman, K. T. (2004). The impact of the type of accounting standards on preparers' judgments. Abacus, $40(\mathrm{I}), 76-93$.

Revsine, L., Collins, D. W., Johnson, W. B., Mittelstaedt, H. F., \& Soffer, L. C. (I999). Financial reporting \& analysis. Upper Saddle River New Jersey: Prentice-Hall.

Smyth, R., \& Söderberg, M. (2010). Public interest versus regulatory capture in the Swedish electricity market. Journal of Regulatory Economics, 38(3), 292-312.

Srivastava, A., Sunder, S., \& Tse, S. (2015). Timely loss recognition and termination of unprofitable projects. China Journal of Accounting Research, 8(3), I47-167.

Tendeloo, B. v., \& Vanstraelen, A. (2005). Earnings management under German GAAP versus IFRS. European Accounting Review, I4(I), I55-I80.

Umoren, A. O., \& Enang, E. R. (2015). IFRS adoption and value relevance of financial statements of Nigerian listed banks. International journal of finance and accounting, 4(I), I-7.

Uyar, M. (2013). The Impact of Switching Standard on Accounting Quality. Journal of Modern Accounting and Auditing, 9(4), 459-479.

Vishnani, S., \& Shah, B. (2008). International differences in the relation between financial reporting decisions and value relevance of published financial statements-with special emphasis on impact of cash flow reporting. International Research Journal of Finance and Economics, I7(I), I450-2887.

Watts, L., \& Zimmerman, J. L. (I986). Positive Accounting Theory.

Zamri, N., Rahman, R. A., \& Isa, N. S. M. (2013). The impact of leverage on real earnings management. Procedia Economics and Finance, 7, 86-95.

\section{Copyrights}

Copyright for this article is retained by the author(s), with first publication rights granted to the journal. This is an open-access article distributed under the terms and conditions of the Creative Commons Attribution license (http://creativecommons.org/licenses/by/4.0/). 